\title{
A Case of Persistent Tardive Dyskinesia in Bipolar Mania
}

\author{
Ong Kheng Yee ${ }^{1}$
}

\section{ÖZET:}

iki uçlu manide inatçı tardiv diskinezi olgusu

Bay CK 49 yaşında iki uçlu bozukluk tip 1 tanısı ile takipli, depresif dönemi olmayan çin'li erkek hasta. Takibinde tam düzelme hiçbir zaman gelișmeyen hastanın hastalıg̃ına karşı içgörü azlıg̃ından dolayı 3 kere yatırılarak tedavi edildi. Hastanın beklenmeyen tardiv diskinezisi hipomanik dönemde hastalıg̃ının 15. yılından sonrasında ilk defa ortaya çıktı. Bu haraketler son manik döneminde arttı ve devamlılık gösterdi ve ayrıca manik dönemin gerilemesi ile belirtiler kayboldu. Manik dönemdeki tardiv diskinezinin görünümü ile ilgili vaka sunumları dopamin-reseptör aşırı duyarlıı̃̃ı ile açıklanırken dig̃erlerinde hareketler sadece depresif dönemde oluşur. Bizim vakamızda tardiv diskinezi riski hastanın ilerlemiş yașı, geçmiş dönemdeki manik hecmelerin varlığı, depresif dönemlerin olmayıșı ve lityum ile ilişkili uzamış yetersiz tedavi ile artmıştır. Bay CK'nın son manik dönemin tedavisi ile ișlevsellig̃inin en iyi seviyesine ulaștı ve sonraki tardiv diskinezi tekrarlanması önlendi.

Anahtar sözcükler: iki uçlu bozukluk, mani, depresyon, inatçı tardiv diskinezi

Journal of Mood Disorders 2013;3(3):128-30

\begin{abstract}
:
A case of persistent tardive dyskinesia in bipolar mania

Mr. CK, a 40-year-old Chinese gentleman is a Bipolar I Disorder patient with no history of depressive episodes. He had never achieved full remission and had 3 previous admissions for manic episodes due to poor insight to his illness. Patient experienced his first manifestation of unexpected tardive dyskinesia in the hypomanic phase after more than 15 years. The movement persisted and was exacerbated by his recent manic episode and almost disappeared when the manic symptoms resolved. There were case reports of the appearance of tardive dyskinesia in manic phase associated with dopamine-receptor supersensitivity, while in others the movement occurred in the depressive phase only. In this case, the risk of tardive dyskinesia increased with patient's advancing age, with past history of multiple manic relapses and no depressive episode and with the prolonged inadequate treatment with lithium. Mr. CK attained optimum level of functioning and further recurrence of tardive dyskinesia was prevented with the remission of his recent manic episode.
\end{abstract}

Key words: bipolar disorder, mania, depression, persistent tardive dyskinesia

Journal of Mood Disorders 2013;3(3):128-30
'MBBS (IMU); M.MED (PSY) (USM), Hospital Duchess of Kent, Malaysia

Yazıșma Adresi / Address reprint requests to: Ong Kheng Yee,

Hospital Duchess of Kent, KM 3.2 Jalan Utara,

90000 Sandakan, Sabah, Malaysia

Elektronik posta adresi / E-mail address: kenoky05@yahoo.com

Telefon / Phone: 06-089-212111

Faks / Fax: 06-089-213607

Kabul tarihi / Date of acceptance 25 Haziran 2013 / June 25, 2013

\section{Bag̃ıntı beyanı:}

G.H.S., C.S., E.O.., G.E., 0.T.: Yazarlar bu makale ile ilgili olarak herhangi bir çıkar çatıșması bildirmemișlerdir.

Declaration of interest:

G.H.S., C.S., E.Ö., G.E., 0.T.: The authors reported no conflict of interest related to this article.

\section{INTRODUCTION}

Bipolar disorder is a mood disturbance with a significant disability and morbidity. Literature has shown that bipolar illness could be complicated by the occurrence of tardive dyskinesia, an abnormal and involuntary choreo-athetoid movement (1). There have been case reports of the appearance of tardive dyskinesia in manic episodes of bipolar illness (2). The appearance of such movement in manic phase is postulated to be associated with dopamine-receptor supersensitivity (2). However, most case reports have shown the reversal of dyskinesia occurrence with its appearance in the depressive episode and disappearance during the manic episode $(3,4)$. Few studies noted that patients with bipolar disorder had a higher prevalence rate of experiencing tardive dyskinesia than that of schizophrenia patients $(5,6)$ while other studies found that they had similar rates with schizophrenia patients' $(7,8)$. Although tardive dyskinesia appeared to be associated with depression, Mukherjee et al (1986) did not find any cases of persistent tardive dyskinesia among the manic patients (9). This case illustrates a bipolar patient's long journey to recovery. After about 15 years from his initial diagnosis, his recent manic episode became unexpectedly complicated by the emergence of tardive 
dyskinesia. The dyskinetic movement persisted from the hypomanic to manic phase and became increasingly incapacitating to patient.

\section{CASE REPORT}

Mr. CK was a 40-year-old Chinese gentleman and married with no children. He was known to be suffering from Bipolar I Disorder (according to DSM-IV-TR criteria) for more than 15 years with no history of depressive episodes. Since diagnosed with the illness, patient was prescribed with tablets lithium carbonate and chlorpromazine. Both medications were either not taken for the whole day or taken in irregular doses with lithium carbonate ranging from 300 to $600 \mathrm{mg}$ per day and chlorpromazine from 50 to $100 \mathrm{mg}$ per day. He had never achieved full remission and had three admissions to hospital from 1995 to 2003 for manic episodes due to poor adherence to medication secondary to poor insight to his illness. Throughout his clinic follow-ups after 2003, patient was in the hypomanic phase with sub-therapeutic serum lithium levels of below $0.2 \mathrm{mmol} / \mathrm{l}$. With the partial treatment, $\mathrm{Mr}$. CK would occasionally become increasingly irritable when agitated by others and appear talkative than his usual self. Nonetheless, he was able to work as a lorry attendant in carrying heavy loads but required supervision from his father so that he would not overworked himself.

In November 2011, Mr. CK developed sudden involuntary choreo-athetoid movements of his left-sided neck that was rather distressing and affected his work performance at times. The dyskinetic movement was the first time it had manifested throughout the course of his illness. There was no other neurological symptom or sign or history of any illicit drug use. All blood investigations were normal. Patient did not seek any treatment for the movement initially as he could still tolerate it then. However, the dyskinesia became progressively worse in terms of frequency and intensity when he became manic towards the end of January 2012 due to non-adherence to his medication for 2 weeks' duration. Following that, admission to hospital was warranted as patient had overt grandiosity with many business plans to venture into, increasing talkativeness and irritability and appeared energetic despite only few hours of sleep. Clinically, flight of ideas and persecutory delusion were present that rendered him incapacitated for work even with supervision from his father. Tablet Quetiapine XR was then initiated. After 2 weeks on Quetiapine with maximum dose of $800 \mathrm{mg}$ ON, Mr. CK's manic symptoms appeared to subside and the dyskinetic movement had reduced substantially.

However on the $3^{\text {rd }}$ week, tablet Sodium Valproate $200 \mathrm{mg}$ BD was added as patient became highly agitated, restless and provocative to others with increasing severity of flight of ideas. The dyskinesia then became worse again with increased intensity. The movements were rated weekly by using the Abnormal Involuntary Movement Scale (AIMS) for the 4 weeks while patient was in ward. The AIMS summed score of items 1 to 7 was 12 i.e. 4 on week 1, 2 on week 2,4 on week 3 and 2 on week 4 . Prior to discharge from ward, Mr. CK's manic symptoms had resolved and his dyskinetic movement appeared to be much less compared to that on admission day. His medications on discharge were Quetiapine XR 600mg ON and Sodium Valproate 400mg BD. The level of serum Sodium Valproate was within acceptable range.

Two weeks later on follow-up in clinic, Mr. CK's illness appeared to be in remission and he had been adherent to and tolerated his medication. The dyskinesia had significantly decreased with AIMS score of 1 and he was working well as a lorry attendant without supervision from his father. In fact for the past 2 months, Mr. CK felt motivated to work and had attained good insight to his illness. His recent Global Assessment of Functioning scale score was 90, a much improvement from the initial score of 25 prior to ward admission. Patient was also advised to have regular daily structured routine and to avoid any unnecessary excessive work.

\section{DISCUSSION}

After more than 15 years of suffering from bipolar disorder, Mr. CK experienced his first episode of tardive dyskinesia in the hypomanic phase of the illness. The subsequent full-blown manic phase exacerbated the movement. Throughout the period of hospitalization, the dyskinesia appeared to lessen in severity when his manic symptoms subsided but increased when the symptoms worsen. After remission was achieved with Quetiapine XR and Sodium Valproate, the dyskinesia was then significantly reduced and patient was functioning well ever since diagnosed with the illness. The concept of dopaminereceptor supersensitivity hypothesized that the gradual 
disappearance of dyskinesia with improvement of his manic symptoms was due to reduced sensitivity of the receptors.

The appearance of dyskinesia during the hypomanic phase may not be influenced by his erratic dose of lowpotency chlorpromazine and the serum lithium level was noted to be below $0.2 \mathrm{mmol} / 1$ (i.e. below the targeted maintenance range of 0.6 to $0.8 \mathrm{mmol} / \mathrm{l})$. Furthermore, patient had stopped taking his medication for two weeks prior to the recent manic phase and the dyskinesia progressively became worse during the phase. As such the emergence of tardive dyskinesia could be likely explained by the underlying pathophysiology of the illness itself i.e. the dopamine-receptor supersensitivity. Waddington et al (1989) reported that tardive dyskinesia in patients with bipolar illness who were exposed to antipsychotics and lithium was associated more with the illness itself than the duration or dosage of medication.(1) Even when cumulative effects of the medication could be partly responsible for the dyskinesia, Mr. CK had established high vulnerability to develop it due to his advancing age, past history of frequent

\section{References:}

1. Waddington JL, Brown K, O’Neill J, McKeon P, Kinsella A. Cognitive impairment, clinical course and treatment history in out-patients with bipolar affective disorder: relationship to tardive dyskinesia Psychological Medicine 1989;19:897-902.

2. Potter RW, Linkowski P, Mendlewicz J. State-dependent tardive dyskinesia in manic-depressive illness. J Neurol Neurosurg Psychiatry 1983;46:666-8.

3. Karaaslan MF, Oguz A, Esel E. Mood-dependent tardive dyskinesia: A case report. Erciyes Med J. 1994; 16:396-9.

4. Scappa S, Teverbaugh P, Ananth J. Episodic tardive dyskinesia and parkinsonism in bipolar disorder patients. Can J Psychiatry 1993;38:633-4.

5. Cavazzoni PA, Berg PH, Kryzhanovskaya LA, Briggs SD, Roddy TE, Tohen M, Kane JM. Comparison of treatment-emergen extrapyramidal symptoms in patients with bipolar mania and schizophrenia during olanzapine clinical trials. J Clin Psychiatry 2006;67:107-13. manic relapses in the absence of depressive episodes and prolonged inadequate treatment with lithium (1).

Olanzapine would probably be better in this case with no history of previous depressive episodes. However Quetiapine XR was the preferred treatment as it had lower propensity for tardive dyskinesia with its loose D2-binding capacity,(10) though precaution was taken to monitor for exacerbation of the movement. With the combined treatment of Quetiapine and Sodium Valproate, patient had not only attained the motivation and commitment to work but also good insight to his illness.

\section{CONCLUSION}

After three previous manic relapses, Mr. CK experienced persistent emergence of unexpected tardive dyskinesia that became progressively worse from the hypomanic to the manic state. With the remission of manic symptoms, Mr. CK could function to his optimum level as well as subdued the appearance of the movement and prevented further its recurrence.

6. Keck PE, McElroy SL, Strakowski SM, Soutullo CA. Antipsychotics in the treatment of mood disorders and risk of tardive dyskinesia. J Clin Psychiatry 2000;61:33-8.

7. Kane JM. Tardive dyskinesia in affective disorders. J Clin Psychiatry 1999;60:43-7.

8. Khanna R, Das A, Damodaran SS. Prospective study of neurolepticinduced dystonia in mania and schizophrenia. Am J Psychiatry 1992;149:511-3.

9. Mukherjee S, Rosen AM, Caracci G, Shukla S. Persistent tardive dyskinesia in bipolar patients. Arch Gen Psychiatry 1986;43:342-6.

10. Seeman P. Atypical Antipsychotics: Mechanism of Action. Can J Psychiatry 2002;47:27-38 